\author{
소의 모발 멜라닌 색소 함량의 품종별 비교 분석 \\ 이성수* · 강승률* · 한상현* · 조인철* · 신광윤* . 조용일* . 강태영* . 고문석*, 양영훈** \\ 농촌진흥청 난지농업연구소*, 제주대학교 동물자원과학과**
}

\title{
Comparative Analysis of Melanin Contents in Hairs among Cattle Breeds
}

\author{
S. S. Lee*, S. R. Kang*, S. H. Han*, I. C. Cho*, K. Y. Shin*, Y. I. Cho*, T. Y. Kang*, M. S. Ko* \\ and Y. H. Yang**
}

National Institute of Subtropical Agriculture, Rural Development Administration*,

Department of Animal Biotechnology, Cheju National University**

\begin{abstract}
To characterize the colorization patterns of bovine hairs, the melanin contents were quantitatively assayed and compared among cattle breeds. The total melanin levels measured by spectrophotometric assay ( $\left.\mathrm{A}_{500}\right)$ from Jeju Black cattle were significantly lower than those from Holstein or Angus with black coat color but significantly higher than those from Hanwoo with yellow coat color or Angus and Holstein with red coat color $(\mathrm{P}<0.001)$. The total melanin levels from Hanwoo were significantly lower than those from Red Angus and Red Holstein but significantly higher than those from Hanwoo $\times$ Charolais crossbred $(\mathrm{P}<0.001)$. The relative ratios of eumelanin to pheomelanin $\left(\mathrm{A}_{650} / \mathrm{A}_{500}\right)$ were $0.382,0.359,0.112$ and 0.124 in Angus, Jeju Balck cattle, Red Holstein and Hanwoo, respectively. These results show that the spectrophotometric method provides a convenient way to qualitatively characterize hair melanin and may be useful for studying expression of major coat color genes in Hanwoo and Jeju Black cattle.
\end{abstract}

(Key words : Melanin, Eumelanin, Spectrophotometer, Cattle hair, Breed)

$$
\text { I. 서 론 }
$$

소에서 모색은 품종의 특징을 구분하는 주요 형질 중 하나로, 개체 및 품종을 식별하기 위 한 기준으로 이용되기도 하는 대표적인 질적 형질이다. 백색, 흑색, 황색, 적색으로 크게 구 분되나 이들이 혼재된 양상을 보이거나 국소적 인 반점 등 다양한 표현형을 보이기도 한다.

모색 유전 연구는 유전학뿐만 아니라 진화, 발달생물학 등의 연구 분야에서도 중요한 역할
을 담당하고 있다. 포유동물에서 약 100 개 이 상의 유전자들이 모색형성과정(pigmentation)에 관여하는 것으로 추정되며, 현재까지 염기서열과 기능이 밝혀진 것은 60 여 개 정도이다(Jackson, 1994; Hoekstra, 2006). 소에서도 melanocortin 1 receptor(MC1R) 유전자(Klungland 등, 1995; Joerg 등, 1996; Kriegesmanm 등, 2001; Rouzaud 등, 2000)를 비롯하여 tyrosinase(TYR), tyrosinaserelated protein(TRP-1), dopachrome tautomerase (DCT) 등 색소세포 내 melanin 합성에 관여하

Corresponding author : Moon-Suck. Ko, National Institute of Subtropical Agriculture, R.D.A. Jeju, Jeju 690-150, Korea.

Tel : 064-754-5710, e-mail : Koms21c@rda.go.kr 
는 유전자(Guibert 등, 2004), 그리고 agouti 유 전자(Girardot 등, 2005; Royo 등, 2005; Girardot 등, 2006) 등의 염기서열과 모색 발현과의 관계 가 보고되고 있다. 국내의 모색 유전 연구는 한우, 제주흑우 그리고 칡소 등에서 $M C 1 R$ 유 전자를 중심으로 연구가 진행되었고, 특히 한 우육과 젖소육의 판별에 이 유전자의 유전자형 분석이 광범위하게 이용되고 있다(이 등, 2000; 정 등, 2000).

포유동물의 모색은 주로 두 가지 색소, 즉 pheomelanin(red/yellow)과 eumelanin(black/brown) 의 분포에 따라 결정되어 진다(Jackson, 1993). 사람과 마우스 등 여러 동물에서 모색 유전, 모색의 정량적 분석 결과들이 보고되고 있다 (Lamoreux 등, 2001; Borges 등, 2001; Wakamatsu 와 Ito, 2002; Ito와 Wakamatsu, 2003; Hennessy 등, 2005). 말의 여러 모색에 따른 색소 함량의 차이가 보고되었고(Sponenberg 등, 1988), 소에 서도 Holstein, Limousine, Charolais, Chianina 등 에서 high performance liquid chromatography (HPLC)를 이용한 정량분석 결과가 보고된 바 있다(Renieri 등, 1993).

현재 대부분의 소품종들은 품종형성과정에서 동질화를 통해 한 가지 모색만을 나타내는 것 이 보통이나, 여타 다른 동물에서와 마찬가지 로(Hoekstra, 2006), 개체의 나이나 계절, 기후 및 환경에 따라 일시적 또는 점진적으로 모색 의 변화가 관찰되기도 한다. 현존하는 한우, 제 주흑우의 집단에서도 각각 황갈색, 흑색의 범 위에 있기는 하지만, 색의 명암이나 농도에서 는 개체 간 차이가 관찰되고 있다. 아직까지 한우와 제주흑우 등에서 모색에 대한 객관적인 기준이 없이 단지 육안 관찰에 의해 황갈색과 흑색의 범주를 적용하고 있으며, 이를 명확히 제시할 수 있는 분석법은 개발되지 못하고 있 다. 우리나라에서 사육되고 있는 재래소 계통 들의 모색의 경우, 한우는 황갈색, 제주흑우는 흑색, 칡소는 호반모의 고유한 무늬 등, 단편적 인 기준만을 가지고 계통구분에 적용하고 있으 나, 과거 한우의 모색 분포만 보더라도 황갈색
이외에도 다양한 모색이 존재했던 것으로 전해 지고 있어(김, 1963; 이 등, 1970; 박 등, 1971), 모색에 대한 명확한 판단기준을 설정할 필요가 대두되고 있다. 이에 본 연구는 한우와 제주흑 우의 모색 특성을 파악하고, 이들 모색의 수치 화 및 주요 모색 관련 유전자 분석의 기초 자 료를 제공하고자 품종별 melanin 함량 특성 분 석을 수행하였다.

\section{ㅍ. 재료 및 방법}

\section{1. 실험재료}

소 품종별 모색 특성을 파악하기 위하여 농 촌진흥청 난지농업연구소 사육 중인 한우 26 두 와 제주흑우 18 두에서 기갑과 앞다리 사이의 어깨부위에서 채취된 모발 시료를 이용하였다. 흑모색 품종으로 제주도 소재 제동목장 Angus 14 두와 일반 농가에서 사육 중인 Holstein 3두 의 흑반, 적모색 품종으로 제동목장 $\mathrm{Red}$ Angus1두와 농가의 Red Holstein 2두, 백모색 품종으로는 Charolais 3두와 Holstein 품종 4두 에서 백반 부위의 모발을 채취하여 분석에 이 용하였다. 또한 한우 $\times$ Charolais 교잡종 6 두를 이용하였다. 계절적 차이를 없애기 위하여 모 발의 채취는 동일 계절에 수행하였으며, 불순 물 제거를 위하여 멸균된 이차증류수로 2회 세척 후 에탄올로 2회 추가 세척한 후 분석에 이용하였다.

\section{2. 소 품종별 멜라닌 상대량 측정과 함량 확 인}

분광광도법을 이용하여 여러 소 품종에서 수 집한 모발에 대한 멜라닌의 상대적 함량을 분 석하였다. 상대량 측정은 Wakamatsu와 Ito의 방 법(2002)과 Lamoreux 등의 방법(2001)을 변형하 여 수행하였다. 먼저, $2 \mathrm{mg}$ 의 모발을 $1 \mathrm{ml}$ 추출 액 soluene 350:Water $=9: 1(\mathrm{v} / \mathrm{v})$ 에 넣고 45 분 동 안 boiling water bath에서 가열하여 용해하였다. 
냉각한 시료는 Cary $100 \mathrm{UV}$-Vis spectrophotometer (Varian, USA)으로 흡광도 $\mathrm{A}_{500}$ (total melanin)과 $\mathrm{A}_{650}$ (eumelanin)에서 측정하였다. 전체 멜라닌 중 eumelanin과 pheomelanin의 상대량은 Ozeki 등 의 방법(1996)에 준하여 결정하였다. 또한, 분광 광도법으로 얻어진 eumelanin의 상대량은 공시 된 품종 중 흑모색은 Angus와 제주흑우, 적색 은 Red Angus, 황색은 한우, 한우 $\times$ Charolais 교 잡종 그리고 백색은 Holstein 백반을 대상으로 각 각 1 두씩 Borges 등(2001)의 방법에 따라 HPLC system/600E(Waters, USA)으로 확인하였다. 개 체별로 $5 \mathrm{mg}$ 의 모발을 water- $0.5 \mathrm{M} \mathrm{NaOH}-3 \%$ $\mathrm{H}_{2} \mathrm{O}_{2}$ 가 들어있는 추출액에 넣고, internal standard $40 \mathrm{nmol}$ phthalic acid를 첨가한 후, boiling water bath에서 20 분간 가열하여 멜라닌을 추출한 후 냉각하였다. 추출액에 $20 \mu \mathrm{ll} 10 \% \mathrm{Na}_{2} \mathrm{SO}_{3}$ 와 250 $\mu \mathrm{l} 6 \mathrm{M} \mathrm{HCl}$ 을 첨가하고, ethyl acetate로 두 번 추출하였고 $45^{\circ} \mathrm{C}$ 풍건 하에서 건조한 후 $1 \mathrm{ml}$ 의 이동상 용액으로 녹였다. 이동상으로는 $0.01 \mathrm{M}$ potassium phosphate 완충액 ( $\mathrm{pH}$ 2.1)과 methanol 을 사용하였고, 유속 $0.8 \mathrm{ml} / \mathrm{min}$ 으로 상기 연구 보고의 이동상 비율(용매강도) 변화에 따라 설 정하였고, 주입량 $100 \mu \mathrm{l}$ 및 $\mathrm{UV}$ 검출기 $(280 \mathrm{~nm})$ 를 이용하여 분석을 실시하였다.

\section{3. 품종별 멜라닌 상대량의 통계 분석}

소에서 여러 가지 모색을 나타내는 품종별 로 얻어진 멜라닌 색소의 상대량의 품종간 비교분석을 위해, 총 melanin과 eumelanin/total melanin의 통계적 유의성 검정을 수행하였다. 통계분석은 SAS package(SAS, 1988)를 이용하 였고, Duncan 다중검정과 상관분석을 실시하 였다.

\section{III. 결과 및 고찰}

소의 다양한 모색을 나타내는 품종들에서 수 집한 모발을 대상으로 전체 melanin 색소 중 흑색을 나타내는 eumelanin의 상대량을 분광광
도법으로 분석하였다. Fig. 1은 소의 여러 품종 에서 전체 melanin의 양을 측정한 것이다. 흑색 품종인 홀스타인, Angus가 여타 다른 품종에 비해 상대적으로 높은 전체 melanin 수준을 나 타내었고, 제주흑우는 황색, 적색 품종들 보다 는 높았으나, 같은 흑색 품종인 홀스타인이나

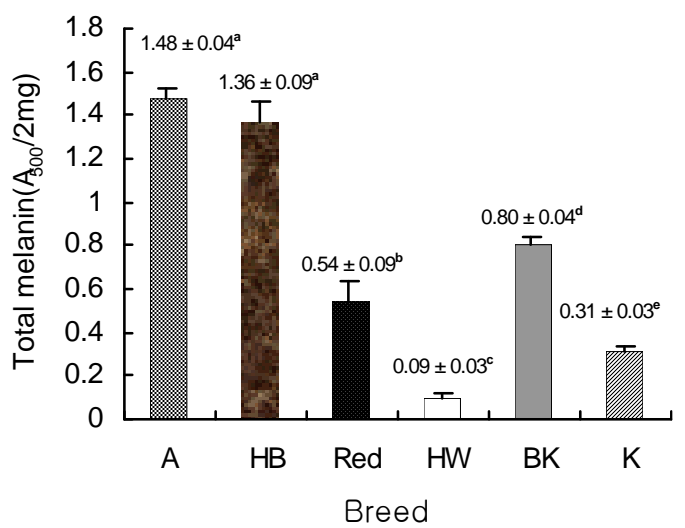

Fig. 1. Total melanin levels measured by spectrophotometric method among cattle breeds. A : Angus, HB : Holstein-black hair, Red : Red Holstein or Red Angus, HW : Holstein-white hair, BK:Jeju Black Cattle, K: Hanwoo. Means marked by different superscripts on the bars within the graph are significantly different $(P<0.001)$.

Angus 보다 낮았다 $(\mathrm{P}<0.001)$, 제주흑우에서 같 은 흑모색인 홀스타인과 Angus 보다 낮은 총 melanin 함량을 나타내는 것은 제주흑우가 완 전한 흑모색 계통이 아닐 가능성을 시사하고 있다. 흑모색 발현에 중요한 $M C 1 R$ 유전자에 대한 품종별 유전자형 연구 보고(Klungland 등, 1995; 이 등 2000)에서 제주흑우는 홀스타인과 Angus의 구조적으로 기능이 강화된 우성 대립 인자인 $E^{D}$ 가 아니라 야생형인 $E^{+}$대립인자를 나타내었다. 제주흑우의 전체 melanin 수준이 Angus나 Holstein 흑반보다 낮게 나타나는 것이 $\mathrm{MC1R}$ 유전자의 대립인자형과 연관된 것으로 추정되나, e/e 유전자형인 한우의 전체 멜라닌 함량이 같은 e/e 유전자형인 Red Holstein이나 
Red Angus 보다 유의적으로 낮은 수준을 보이 고 있어, 한우와 제주흑우에서 $M C 1 R$ 유전자 외에 다른 유전적 요인이 melanin 함량에 영향 을 미치는 것으로 사료된다. 특히 $M C 1 R$ 유전 자형이 동일한 한우와 적색 품종들(Red Angus, Red Holstein)과의 전체 melanin 수준의 차이는 melanin 침착에 $M C 1 R$ 이외의 유전자의 작용하 고 있음을 보여주는 중요한 결과라 할 수 있을 것이다.

Fig. 2는 한우와 Charolais, 이들의 그 교잡종 인 $\mathrm{C} \times \mathrm{K}$ 의 전체 melanin 수준을 보여주고 있 다. 최근의 Guibert 등(2004)의 보고에 따르면 Charolais 품종 피부에서 추출된 RNA를 이용 real-time RT-PCR 분석 결과 색소세포 내 melanin 합성에 직접적으로 관여하는 TYR, TRP-1, DCT 유전자의 발현 정도가 상당히 높은 것으로 나 타났다. 그럼에도 모발에서 Charolais는 Holstein 백반과 비슷한 수준의 총 melanin 함량을 보였 고, $\mathrm{C} \times \mathrm{K}$ 교잡종은 한우와 Charolais의 중간 수 준의 melanin 함량을 나타내고 있어 $(\mathrm{P}<0.001)$ 아 직까지 보고되지 않은 또 다른 유전적인 요소 가 Charolais 백색과 한우의 황색의 발현에 관

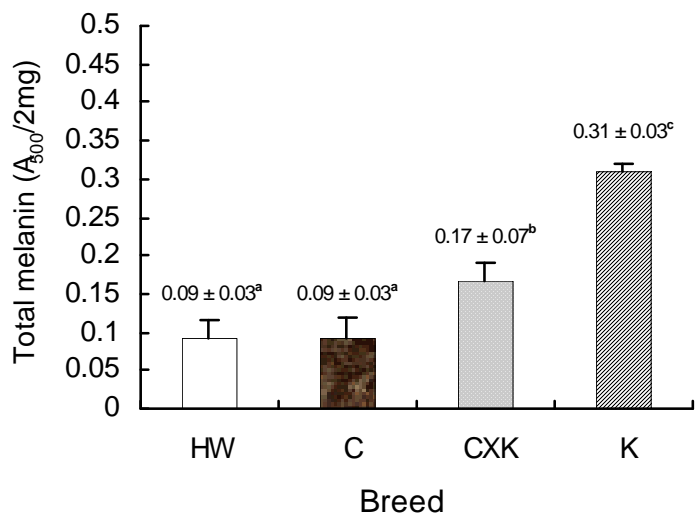

Fig. 2. Total melanin levels measured by spectrophotometric method among cattle breeds. HW: Holstein-white hair, K: Hanwoo, C: Charolais, CXK: Charloais XHanwoo crossbred. Means marked by different superscripts on the bars within the graph are significantly different $(P<$ 0.001)
여하고 있는 것으로 사료된다. 또한 $\mathrm{CK}$ 에서 완 전한 백색이나 황색이 아닌 중간형의 표현형은 이 유전자가 dilution에 작용을 가지고 있을 것 으로 판단되며 이들 $\mathrm{F} 1$ 개체들 간의 교배를 통 하여 F2에서 모색 발현 양상을 분석한다면 이 모색 발현에 관여하는 유전자의 탐색이 가능하 리라 사료된다.

Wakamatsu와 Ito (2002) 등은 eumelanin과 pheomelanin이 650-500 nm에서의 흡광도에서 유의적으로 차이가 있고, 그 흡광도의 비율이 pheomelanin과 eumelanin의 상대적 수준 측정에 이용될 수 있음을 보고하였고, Ozeki 등(1996) 은 $\mathrm{A}_{650} / \mathrm{A}_{500}$ 비율이 전체 melanin 중 eumelanin 의 상대적인 비율과 상당히 깊은 관련이 있음을 보고한 바 있다. 이와 관련하여 Fig. 3은 소의 모색과 품종에 따른 전체 melanin 중 eumelanin, pheomelanin의 상대적 수준 $\left(\mathrm{A}_{650} / \mathrm{A}_{500}\right)$ 을 분석 한 결과이다. 흑모색 품종인 Hostein의 흑반, Angus, 제주흑우의 전체 melanin중 eumelanin의 비율은 적모색, 황모색 품종들에 비해 유의적으 로 높은 경향을 나타내고 있었다 $(\mathrm{P}<0.001)$. 제주

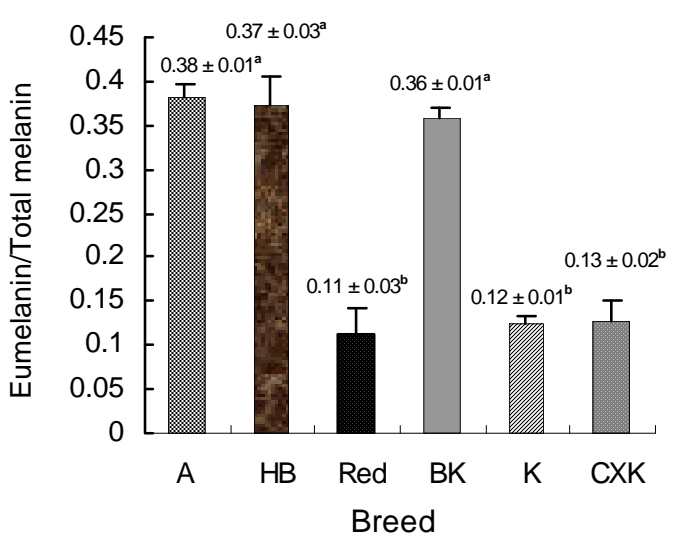

Fig. 3. Ratios of eumelanin/total melanin contents of hairs from different cattle breeds. A : Angus, HB : Holstein-black hair, Red: Red Holstein or Red Angus, BK:Jeju Black Cattle, K:Hanwoo, CXK : Charloais XHanwoo crossbred. Means marked by different superscripts on the bars within the graph are significantly different $(P<$ 0.001). 
흑우의 경우 총 melanin 수준은 Holstein과 Angus 보다 낮은 수준을 나타내었으나, 전체 melanin 중 eumelanin의 상대적인 수준에서는 유의적인 차 이를 나타내지 않아, 제주흑우는 Holstein, Angus 에 비해 eumelanin의 수준뿐만 아니라 pheomelanin 의 수준 역시 이들 품종들에 비해 상대적으로 낮은 수준인 것으로 추정된다. 이 같은 양상 은 한우와 적색품종들 간 비교에서도 전체 melanin 중 eumelanin의 상대적인 비율에서 유 의적인 차이가 관찰되지 않아, 비슷한 양상을 보였다.

이와는 달리 한우와 제주흑우의 총 melanin 수준과 전체 melanin 중 eumelanin의 상대적인 비율간의 상관관계 분석에서는 흑모색인 제주흑 우에서는 정의 상관을, 황갈색인 한우에서는 부 의 상관을 나타내고 있어, 한우에서의 eumelanin 생합성 수준은 제한되어 있는 것으로 사료된다 (Fig. 4). 또한 제주흑우와 한우에서 개체별 차 이를 확인할 수 있었다.

각 품종별 melanin 함량 특성에 대한 분광광 도법적 분석 결과를 확인하기 위하여 HPLC를 이용하여 eumelanin의 양을 측정한 결과는 Fig. 5 와 같다. 분석 결과 Black Angus가 eumelanin 수준이 가장 높았으며 제주흑우, Red Angus, 한우, Charolais $\times$ 한우 그리고 백모 순으로 나타 나 분광광도법적 분석에 의한 측정치와 동일한 경향을 보였다. 이는 상당히 복잡한 전처리 과 정과 고가의 장비를 구비하여야 분석 가능한 HPLC 분석에 비해 분광광도법 분석이 모발 내 melanin 수준을 파악하는데 보다 편리하게 사 용될 수 있는 방법임을 시사하는 결과라 하겠 다.

이상의 연구결과는 소의 품종별 모색에 대한 특성을 melanin 색소의 수준 분석을 통해 어느 정도 수치화된 계량적 정보를 제공할 수 있음 을 보여주고 있으며, 한우와 제주한우에서 모 색발현에서는 MC1R 이외의 유전적인 요인이 관여하고 있음을 보여주고 있었다. 우리나라에 서 사육되고 있는 한우와 제주흑우가 황갈색, 흑색을 기본으로 한 계통임을 의심할 여지없는
사실이나, 색상의 범위와 농도 및 채도에 대한 기준은 모호한 실정이다. 따라서 본 연구에서 제시하고 있는 색소에 대한 정보는 향후, 한우 및 제주흑우, 칡소 등 재래소의 계통 특성화뿐 만 아니라, 소에서 모색 표현의 강약을 조절하 는 유전적인 요인 등을 분석하는 데 있어 중요 한 기초 자료가 될 것으로 사료된다.

\section{[A]}

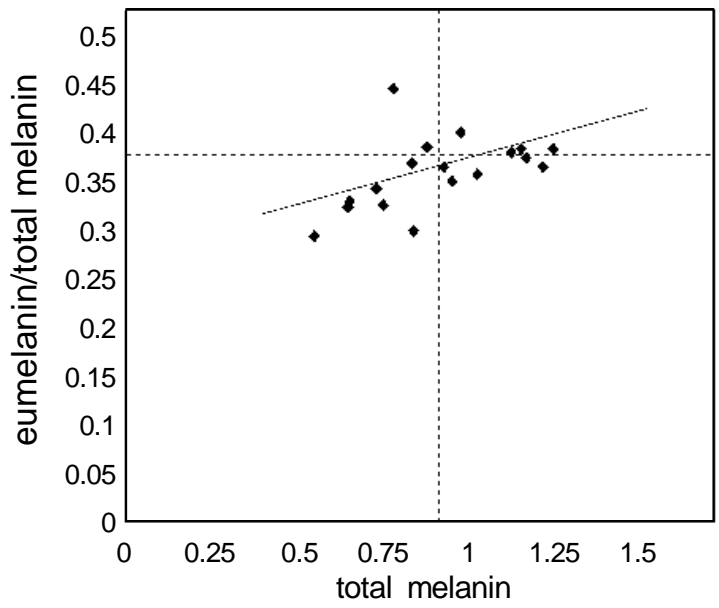

Eumelanin/total melanin $=0.264+0.098$ total melanin $\left(R^{2}=0.11\right)$ $(0.0001)(0.09)$

[B]

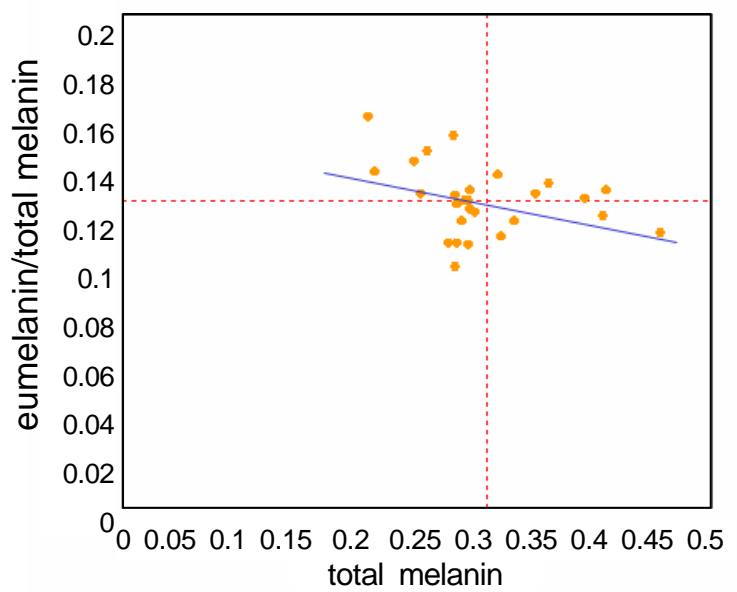

Eumelanin/total melanin $=0.15-0.08$ total melanin $\left(R^{2}=0.11\right)$ (0.0001) (0.09)

Fig. 4. Correlation graph of total melanin content with the ratio of eumelanin/total melanin. [A] Jeju Black Cattle, [B] Hanwoo. 

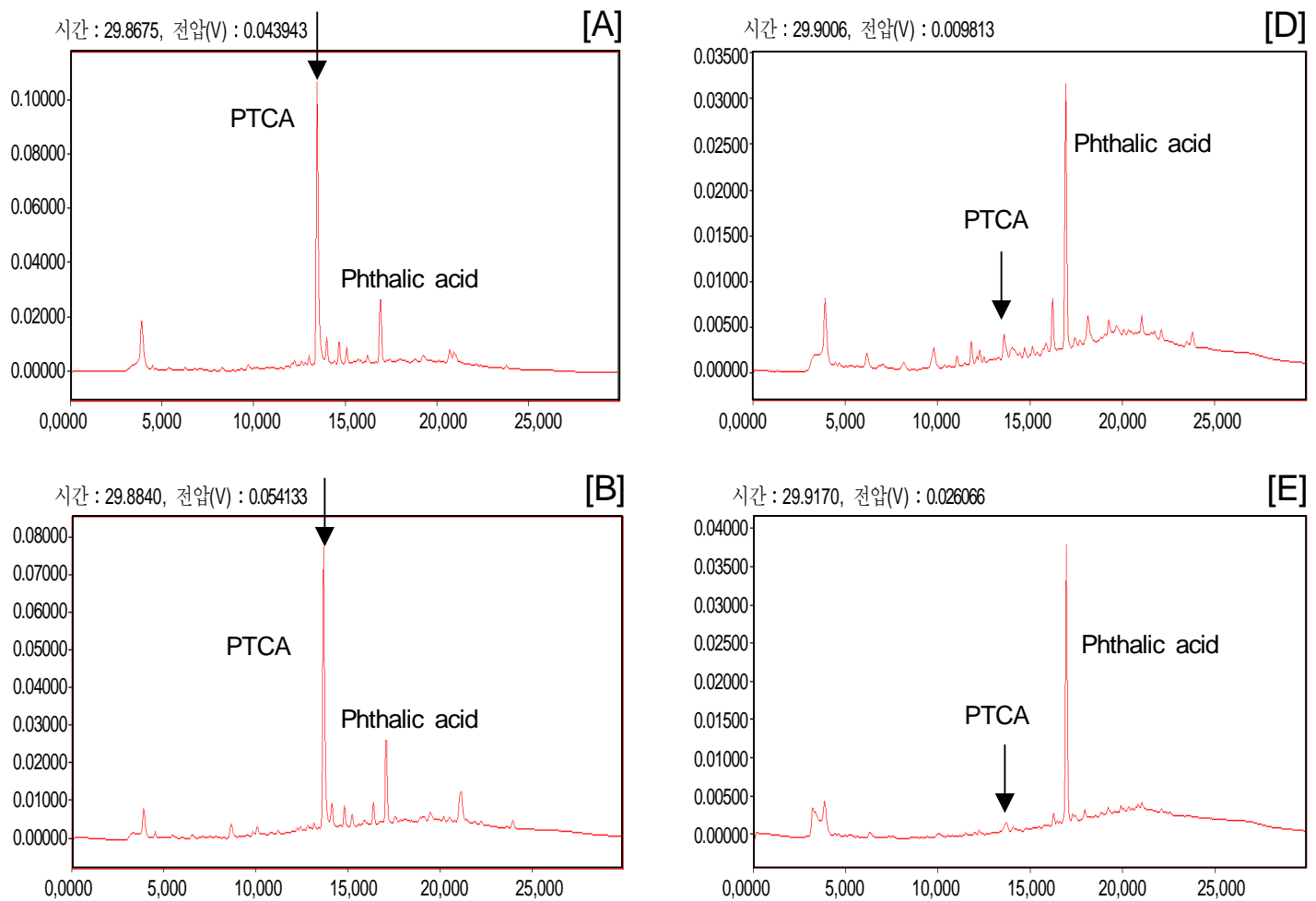

시간 : 29.9336, 전압(V) : 0.019896

[C]

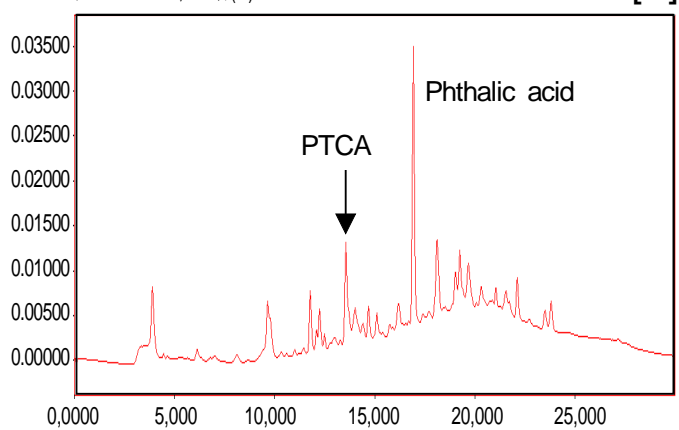

시간 : 29.8840 , 전압 $(\mathrm{V}): 0.014787$ $[\mathrm{F}]$

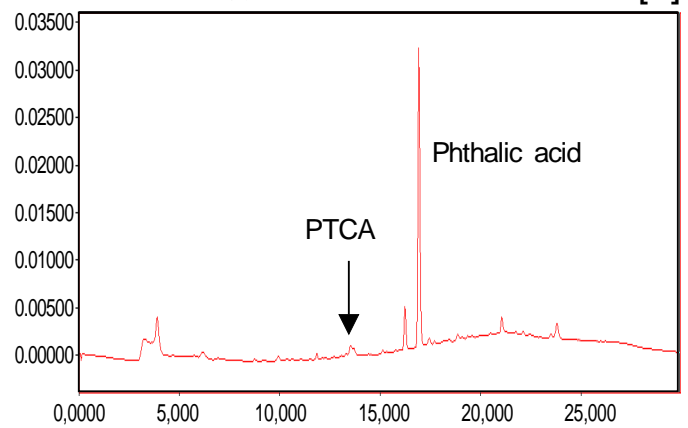

Fig. 5. HPLC Chromatograms of eumalanin among cattle breeds. Hair samples were oxidized with permanganate to give PTCA and $40 \mathrm{~nm}$ phthalic acid was added as an internal standard. [A] Angus, [B] Jeju Black Cattle, [C] Red Angus, [D] Hanwoo, [E] Charolais $\times$ Hanwoo crossbred, [F] Holstein-white hair.

IV. 요 약

한우와 제주흑우의 모색 특성과 양적 수치화 를 위하여 분광광도법적 분석을 수행하였다. 분 석 결과 제주흑우의 총 melanin 함량은 같은 흑색 품종인 Holstein과 Angus에 비해 유의적으
로 낮았고 한우나 적색 품종 보다는 높은 수준 을 보였다 $(\mathrm{P}<0.001)$. 한우의 총 melanin 함량은 적색 품종에 비해 유의적으로 낮았고 한우 $\times$ Charolais 교잡종에 비해 높았다 $(\mathrm{P}<0.001)$. 전체 melanin 중 eumelanin, pheomelanin의 상대적 수준 을 분석한 결과 Angus, 제주흑우, Red Holstein과 
한우 각각 $0.382,0.359,0.112$ 와 0.124 이었다. 품종별 모발 melanin 색소 함량 분석결과는 분 광광도법적 분석이 소 품종별 모색의 양적 수 치화 및 특성 비교에 이용 가능하고 한우와 제 주흑우의 주요 모색 관련 유전자 연구의 기초 자료로 유용함을 보여주고 있다.

\section{$\mathrm{V}$. 인 용 문 헌}

1. Borges, C. R., Roberts, J. C., Wilkins, D. G. and Rollins, D. E. 2001. Relationship of melanin degradation products to actual melanin content: application to human hair. Anal. Biochem. 290: 116-125.

2. Giradot, M., Martin, J., Guibert, S., Leveziel, H., Julien, R. and Oulmouden, A. 2005. Widespread expression of the bovine Agouti gene results from at least three alternative promoters. Pigment Cell Res. 18:31-41.

3. Girardot, M., Guibert, S., Laforet, M. P., Gallard, Y. G., Larroque, H. and Oulmouden, A. The insertion of a full-length Bos taurus LINE element is responsible for a transcriptional deregulation of the Normande Agouti gene. Pigment Cell Res. 19:346-355.

4. Guibert, S., Girardot, M., Leveziel, H., Julien, R. and Oulmouden, A. 2004. with the TYR, TYRP1 and DCT transcription levels. Pigment Cell Res. 17:337-345

5. Hennessy, A., Oh, C., Diffey, B., Wakamatsu, K., Ito, S. and Rees, J. 2005. Eumelanin and pheomelanin concentrations in human epidermis before and after UVB irradiation. Pigment Cell Res. 18:220-223.

6. Hoekstra, H. E. 2006. Genetics, development and evolution of adaptive pigmentation in vertebrates. Heredity 97:222-234.

7. Ito, S. and Wakamatsu, K. 1994. An improved modification of permanganate oxidation of eumelanin that gives a constant yield of pyrrole-2,3,5,tricarboxylic acid. Pigment Cell Res. 7:141-144.
8. Ito, S. and Wakamatsu, K. 2003. Quantitative analysis of eumelanin and pheomelanin in humans, mice, and other animals: a comparative review. Pigment Cell Res. 16:523-531.

9. Jackson, I. J. 1994. Molecular and developmental genetics of mouse coat color. Annu. Rev. Genet. 23:189-217.

10. Joerg, H., Fries, H. R., Meiferink, E. and Stranzinger, G. F. 1996. Red coat color in Holstein cattle is associated with a deletion in the MSHR gene. Mamm. Genome 7:317-318.

11. Klungland, H., Vage, D. I., Gomez-Raya, L., Adalsteinsson, S. and Lien, S. 1995. The role of melanocyte-stimulating hormone (MSH) receptor in bovine coat color determination. Mamm. Genome 6:636-639.

12. Kriegesmann, B., Dierkes, B., Leeb, T. Jansen, S. and Brenig, B. 2001. Two breed-specific bovine MC1-R alleles in Brown Swiss and Saler Breeds. J. Dairy Sci. 84:1768-1771.

13. Lamoreux, M. L., Wakamatsu, K. and Ito, S. 2001. Interaction of major coat color gene functions in mice as studied by chemical analysis of eumelanin and pheomelanin. Pigment Cell Res. 14:23-31.

14. Ozeki, H., Ito, S., Wakamatsu, K. and Thody, A. J. 1996. Spectrophotometric characterization of eumelanin and pheomelanin in hair. Pigment Cell Res. 9:265-270.

15. Renieri, C., Ceccarelli, P., Gargiulo, A. M., Lauvergne, J. J. and (Bos taurus) with four types of phenotypic pigmentation. Pigment Cell Res. 6:165.

16. Rouzaud, F., Martin, J., Gallet, P. F., Delourme, D., Goulemot-Leger, V., Amigues, Y., Menissier, F., Leveziel, H., Julien, R. and Oulmouden, A. 2000. A first genotyping assay of french cattle breeds based on a new allele of the extension gene encoding the melanocortin-1 receptor (Mc1r). Genet. Sel. Evol. 32:511-520.

17. Royo, L. J., Alvarez, I., Fernandez, I., Arranz, J. J., Gomez, E. and Goyache, F. 2005. The coding 
sequence of the ASIP gene is identical in nine wild-type coloured cattle breeds. J. Anim. Breed. Genet. 122:357-360.

18. SAS. 1988. SAS user's guide. SAS Inst., Inc., Cary, NC.

19. Sponenberg, D. P., Ito, S., Eng, L. A. and Schwink, K. 1988. Pigment types of various color genotypes of horses. Pigment Cell Res. 1:410.

20. Wakamatsu, K. and Ito, S. 2002. Advanced chemical methods in melanin determination. Pigment Cell Res. 15:174-183.

21. 김환경. 1963 . 제주지방우의 모색분포에 관한 연 구. 동아논총 제 1집:33-45.
22. 박영일, 한성욱. 1971. 제주한우의 모색빈도에 관 한 연구. 한국축산학회지 13:352-255.

23. 이기만. 1970 . 한우의 형질과 그 상관에 관한 연 구. 한국축산학회지 12:141-142.

24. 이성수, 양영훈, 강승률, 오운용, 양보석, 고서봉, 오성종, 김규일. 2000. 한우, 제주재래흑우, 흑모 화우와 갈모화우에서의 MSH receptor(MC1R) 유 전자의 유전자형과 빈도 비교. 한국동물자원과학 회지 42:253-260.

25. 정의룡, 김우태, 김연수, 한상기. 2000. 소 모색관 련 유전자 MC1R의 PCR-RFLP Marker를 이용한 한우육 판별. 한국동물자원과학회지 42:379-390. (접수일자 : 2006. 12. 22. / 채택일자 : 2006. 2. 12.) 